\title{
EFEKTIFITAS MODEL PEMBELAJARAN DIRRECT INSTRUCTION DENGAN STRATEGI MOTIVASI ARCS PADA MATERI GRAPH
}

\section{THE EFFECTIVENESS OF DIRRECT INSTRUCTION MODEL BY MOTIVATION STRATEGY ARCS IN GRAPH LEARNING}

\author{
Yemi Kuswardi Ira Kurniawati, Sutopo \\ Program Studi Pendidikan Matematika FKIP UNS
}

\begin{abstract}
ABSTRAK
Materi Graph berisikan pengetahuan deklaratif dan pengetahuan prosedural. Pada materi ini yang termasuk pengetahuan deklaratif adalah terminologi graph sedangkan yang termasuk pengetahuan prosedural adalah bagaimana menentukan penyelesaian permasalahan-permasalahan dengan menggunakan algoritma yang terkait dengan Graph. Dirrect instruction yang bertumpu pada prinsipprinsip perilaku dan teori belajar sosial, telah dirancang khusus untuk menunjang proses belajar mahasiswa yang berkaitan dengan pengetahuan prosedural dan pengetahuan deklaratif yang terstruktur dengan baik dan dapat diajarkan dengan pola kegiatan yang bertahap, selangkah demi selangkah. Strategi motivasi ARSC (Attention, Relevance, Confidence, Satisfaction) merupakan strategi yang dapat meningkatkan motivasi terhadap materi pembelajaran dan aktifitas belajar mahasiswa. Penerapan model pembelajaran Dirrect instruction dengan strategi motivasi ARCS merupakan salah satu solusi untuk mengatasi masalah tersebut. Tujuan penelitian ini adalah untuk mengetahui apakah dalam penerapan model pembelajaran dirrect instruction dengan strategi motivasi ARCS pada materi graph: (1) ketuntasan belajar mahasiswa tercapai, (2) aktifitas belajar mahasiswa efektif , (3) respon mahasiswa positif, dan (4) keefektifitas model pembelajaran tercapai. Sejalan dengan tujuan penelitian maka penelitian ini merupakan penelitian deskriptif kualitatif. Subyek penelitian ini adalah mahasiswa Program Studi Pendidikan Matematika Jurusan Pendidikan Matematika dan IPA Fakultas Keguruan dan Ilmu Pendidikan Universitas Sebelas Maret Surakarta yang menempuh mata kuliah Matematika Diskrit. Hasil penelitian adalah dalam penerapan model pembelajaran dirrect instruction dengan strategi motivasi ARCS pada materi graph (1) Ketuntasan belajar mahasiswa tercapai, (2) aktifitas belajar mahasiswa efektif , (3) respon mahasiswa tergolong positif, dan (4) efektifitas model pembelajaran tercapai
\end{abstract}

Kata Kunci: Model Pembelajaran Dirrect Instruction, Strategi Motivasi ARCS, Matematika Diskrit, Graph

\begin{abstract}
Graph materials contains declarative knowledge and procedural knowledge. In Graph subject included declarative knowledge is the graph terminology while those included procedural knowledge is how to determine the settlement of problems by using the algorithm methods associated with Graph. Dirrect instruction that relies on principles of behavioral and social learning theory, has been specifically designed to support students' learning processes associated with procedural knowledge and declarative knowledge is well structured and can be taught with the pattern of activity that gradually, step by step. ARSC motivation strategies (Attention, Relevance, Confidence, Satisfaction) is a strategy that can increase the motivation on learning materials and learning activities of students. Application of direct instruction model with ARCS motivational strategies is one solution to resolve the issue. The purpose of this study was to determine whether the aplication of direct istruction model using ARCS strategy on graph materials subject (1) the mastery learning is achieved, (2) students' learning activities are effective, (3) students' responses are positive, and (4) the effectiveness of model is reached. This research is a qualitative descriptive research. The subjects of this research are students who take Discrete Mathematics course in Educational Mathematics Program, Department of Educational Mathematics and Science, FKIP, Sebelas Maret University Surakarta. The results is (1) mastery learning achieved, (2) learning activities are effective, (3) students' response considered positive, (4) the effectiveness of interactive learning on graph is achieved.
\end{abstract}

Keywords: Dirrect Instruction Model, Motivation Strategies ARCS, Discrete Mathematics, Graph 


\section{PENDAHULUAN}

Masalah pendidikan di Indonesia dari tahun ke tahun terus mengalami perubahan. Hal ini dapat kita lihat dengan adaanya perubahan kurikulum baik pada tingkat dasar maupun pada tingkat perguruan tinggi, yang tujuannya tidak lain adalah untuk menyesuikan perkembangan mutu pendidikan dengan perkembangan zaman.

Dalam meningkatkan mutu pendidikan hanya mungkin dicapai dengan meningkatkan mutu proses pendidikan yang didalamnya terdapat interaksi antara siswa, guru, sarana, kurikulum, evaluasi, dan lingkungan. Dari beberapa faktor tersebut dapat bersama-sama atau sendiri-sendiri mempengaruhinya, artinya hasil belajar yang rendah tidak hanya dipengaruhi satu faktor saja. Soedjadi (1992) menyatakan bahwa bukan sesuatu yang mustahil bahwa rendahnya hasil belajar dikarenakan materi kurikulum yang terlalu berat, metode pembelajaran yang tidak tepat, sarana belajarnya yang tidak mendukung atau lingkungan sekolah yang tidak memungkinkan proses pembelajaran berjalan normal.

Dalam pembelajaran matematika tugas seorang pendidik adalah menciptakan kondisi dan situasi pembelajaran yang dapat membangkitkan semangat belajar siswa, sehingga siswa mencintai matematika. Penekanan pembelajaran matematika di sekolah harus relevan dengan kehidupan seharihari, supaya pelajaran matematika yang diperoleh akan terasa manfaatnya. Dengan demikian siswa dapat mengaplikasikan matematika dalam kehidupan sehari-hari. Hal ini akan berdampak positif dalam menciptakan sumber daya manusia yang bermutu. Sehubungan dengan pentingnya peranan matematika, maka sudah seharusnya proses pembelajaran matematika ditangani lebih serius. Pendidik perlu mempersiapkan suatu model pembelajaran yang terprogram agar peserta didik memperoleh pengalaman belajar yang baik.

Kenyataan dilapangan menunjukkan bahwa hasil pendidikan matematika saat ini dapat dikatakan belum memenuhi harapan. Jika ditinjau dari faktor pendidik kemungkinan penyebabnya adalah masih banyak pendidik matematika yang belum mampu memberikan motivasi dalam pembelajaran matematika. Akibatnya, mata pelajaran ini tidak begitu diminati oleh siswa.

Untuk dapat memecahkan masalah di atas, diharapkan pendidik berusaha untuk dapat memotivasi siswa dalam mempelajari matematika, memilih model pembelajaran yang dapat meningkatkan motivasi belajar siswa, dan pendidik harus berusaha menanamkan kepada siswa bahwa pelajaran matematika dapat meningkatkan penalaran, membentuk kepribadian serta dapat dimanfaatkan dalam kehidupan sehari-hari. Jadi diharapkan pendidik harus memiliki kemampuan yang memadai dalam bidang matematika, dan cara mengajar serta cara memotivasi siswa untuk belajar. Menurut Arends (dalam Kardi, 1997) mengemukakan bahwa: "salah satu syarat guru yang berhasil adalah guru yang menguasai sejumlah keterampilan mengajar, sehingga dapat memotivasi siswa untuk berpikir reflektif 
dan mampu memecahkan masalah". Selanjutnya Nur (1998) mengemukakan bahwa: "tugas penting bagi guru adalah merencanakan bagaimana guru akan mendukung motivasi siswa".

Jadi untuk dapat mengajar lebih efektif, dan membuat anak didik merasa senang dan tidak bosan dalam belajar, pendidik harus selalu berusaha untuk memvariasikan proses pembelajaran sehingga dapat membangkitkan motivasi belajar siswa. Motivasi tidak hanya penting untuk menjadikan siswa terlibat dalam kegiatan akademik, namun motivasi juga sangat berperan dalam menentukan seberapa jauh siswa akan belajar dari suatu kegiatan pembelajaran atau seberapa banyak siswa dapat menyerap informasi yang disajikan. Gardner, dkk (dalam Nur, 1998) mengemukakan bahwa: "siswa termotivasi untuk belajar sesuatu akan menggunakan proses kognitif yang lebih tinggi dalam mempelajari materi itu, sehingga siswa itu akan menyerap dan mengendapkan materi itu dengan lebih baik.”

Untuk dapat mencapai tujuan tersebut diperlukan suatu strategi untuk meningkatkan motivasi siswa terhadap materi pembelajaran. Keller (1987: 2) memperkenalkan suatu strategi motivasi ARSC (Attention, Relevance, Confidence, Satisfaction). Selanjutnya Keller (1987: 3) mengemukakan bahwa: "strategi motivasi model ARCS adalah suatu metode untuk meningkatkan motivasi terhadap materi pembelajaran”. Dalam hal ini strategi motivasi ARCS (Attention, Relevance, Confidence, Satisfaction) memiliki strategi yang dapat digunakan untuk meningkatkan motivasi, dan aktivitas siswa dalam belajar.

Dalam strategi motivasi ARCS terdapat kiat-kiat sebagai berikut. (1) Untuk meningkatkan perhatian siswa terhadap materi pelajaran; (2) menghubungkan materi dengan manfaatnya dalam kehidupan sehari-hari; (3) untuk meningkatkan kepercayaan siswa terhadap materi yang diberikan guru; dan (4) untuk mewujudkan kepuasan siswa dalam proses pembelajaran dan materi yang dipelajarinya.

Materi yang terdapat didalam mata kuliah Matematika Diskrit adalah materi tentang Graph. Materi ini berisikan pengetahuan deklaratif dan pengetahuan prosedural. Pengetahuan deklaratif adalah pengetahuan tentang sesuatu. Pengetahuan prosedural adalah pengetahuan tentang bagaimana melakukan sesuatu. Dalam materi Graph pada mata kuliah Matematika Diskrit yang termasuk pengetahuan deklaratif adalah terminologi graph yang membahas mengenai definisi tentang graph dan hal-hal yang terkait dengan Graph sedangkan yang termasuk pengetahuan prosedural adalah bagaimana menentukan penyelesaian permasalahan-permasalahan dengan menggunakan algoritma metode-metode yang terkait dengan Graph. Pengetahuan deklaratif dan pengetahuan prosedural dapat diajarkan secara bertahap. Menurut Arends (2001: 264) Dirrect instruction yang bertumpu pada prinsipprinsip perilaku dan teori belajar sosial, telah dirancang khusus untuk menunjang proses belajar siswa yang berkaitan dengan pengetahuan prosedural dan pengetahuan 
deklaratif yang tersetruktur dengan baik dan dapat diajarkan dengan pola kegiatan yang bertahap, selangkah demi selangkah.”

Menurut Carin (1993: 82) dirrect instruction secara sistematis menuntun dan membantu siswa untuk melalui tahap-tahap pembelajaran tertentu, yang bermaksud untuk melihat hasil belajar dari masing-masing tahap. Sintaks model dirrect instruction menurut Arends (2001: 264) terdiri dari 5 tahap yang harus dilalui; (1) menyampaikan tujuan dan mempersiapkan siswa, (2) mendemonstrasikan pengetahuan, (3) pemberian pelatihan terbimbing, (4) mengecek pemahaman dan memberikan umpan balik, dan (5) memberikan latihan mandiri.

Model dirrect instruction secara sistematis menuntun dan membantu siswa melalui langkah-langkah atau tahapan-tahapan tertentu, dan selanjutnya siswa akan aktif bekerja sendiri dengan adanya kegiatan latihan terbimbing dan latihan mandiri. Ini berarti siswa akan mendapat informasi yang jelas dalam mempelajari suatu materi pelajaran.

\section{METODE PENELITIAN}

\section{Lokasi Penelitian}

Penelitian dilaksanakan di Program Studi Pendidikan Matematika Jurusan Pendidikan Matematika dan IPA Fakultas Keguruan dan Ilmu Pendidikan Universitas sebelas Maret Surakarta.

\section{Subyek Penelitian}

Subyek penelitian adalah mahasiswa Program Studi Pendidikan Matematika Jurusan Pendidikan Matematika dan IPA Fakultas
Keguruan dan Ilmu Pendidikan Universitas Sebelas Maret Surakarta yang menempuh mata kuliah Matematika Diskrit pada tahun ajaran $2010 / 2011$

\section{Metode Pengumpulan Data}

Dalam penelitian ini diperlukan data hasil belajar siswa, data aktivitas siswa dan data tentang respon siswa. Untuk memperoleh data hasil belajar siswa pada materi graph, kepada siswa diberikan tes sesudah kegiatan pembelajaran. Untuk memperoleh data aktivitas siswa selama kegiatan pembelajaran dilakukan observasi oleh 3 orang observator selama kegiatan pembelajaran berlangsung. Untuk memperoleh data tentang respon siswa, kepada siswa diberikan angket respon siswa setelah kegiatan pembelajaran dengan menerapkan model pembelajaran dirrect instruction dengan strategi motivasi ARCS pada materi graph.

\section{Analisis Data}

\section{a. Data Hasil Belajar}

Analisis data hasil belajar siswa secara deskriptif bertujuan untuk mendeskripsikan ketuntasan hasil belajar siswa. Ketuntasan belajar yang dimaksud dalam penelitian ini adalah taraf penguasaan sebagai nilai batas lulus (NBL) berdasarkan Peraturan Rektor Universitas Sebelas Maret tahun 2008.

\section{b. Data Aktivitas Siswa}

Analisis data aktivitas siswa dengan menggunakan percentase bertujuan untuk mengetahui keefektifan aktivitas siswa selama kegiatan pembelajaran. Presentase waktu ideal 
untuk setiap kategori aktivitas siswa dan kriteria pencapaian efektifitas aktivitas siswa dalam pembelajaran dapat dilihat pada Tabel 1 .

Aktivitas siswa dikatakan efektif jika enam dari delapan indikator tersebut memenuhi kriteria batasan efektivitas siswa dengan syarat indikator 4, 5, dan 6 terpenuhi.

\section{c. Data Respon Siswa}

Untuk menentukan kriteria efektivitas respon siswa terhadap komponen dan kegiatan pembelajaran dilakukan sebagai berikut.

i) Dari hasil angket respon siswa dianalisis secara diskriptif dalam bentuk persentase dan dikelompokkan untuk setiap indikator

ii) Respon siswa dikatakan positif apabila persentase yang terbesar dari rata-rata persentase setiap indikator berada dalam

kategori senang, tidak ada kesulitan, ada kemajuan, tertarik, berminat , paham, jelas, dan baik.

\section{d. Kriteria Keefektifan Model Dirrect In-}

\section{struction dengan Strategi Motivasi ARCS}

Keefektifan model dirrect instruction dengan strategi motivasi ARCS dalam pembelajaran materi graph pada mata kuliah matematika diskrit tercapai jika Ketuntasan belajar tercapai, keefektifan aktivitas siswa tercapai dan respon siswa terhadap pembelajaran positif.

\section{HASIL DAN PEMBAHASAN}

Analisis deskriptif dilakukan untuk

Tabel 1. Kriteria Pencapaian Efektifitas Aktivitas Siswa dalam Pembelajaran

\begin{tabular}{|l|c|c|}
\hline \multicolumn{1}{|c|}{ Aktivitas Siswa } & $\begin{array}{c}\text { Waktu } \\
\text { Ideal }\end{array}$ & $\begin{array}{c}\text { Kriteria batasan } \\
\text { efektifitas (\%) }\end{array}$ \\
\hline 1. Memperhatikan/mendengarkan penjelasan pengajar & $20 \%$ & $15-25$ \\
2. Membaca (buku ajar/lembar kerja kelompok) & $10 \%$ & $5-15$ \\
3. Mencatat (yang relevan dengan KBM) & $5 \%$ & $0-10$ \\
4. Mengerjakan/menyelesaikan masalah & $33 \%$ & $28-38$ \\
5. Berdiskusi/bertanya antar siswa,antar siswa dan pengajar & $27 \%$ & $22-32$ \\
6. Mengkomunikasikan hasil kerja kelompok & $5 \%$ & $0-10$ \\
7. Perilaku yang tidak relevan dengan KBM & $0 \%$ & $0-5$ \\
\hline
\end{tabular}

Tabel 2. Hasil Pengamatan Aktivitas Siswa selama Pembelajaran dengan Model Direct Instruction

\begin{tabular}{|c|c|c|c|c|c|c|c|}
\hline \multirow[b]{3}{*}{ Kategori Pengamatan } & \multicolumn{5}{|c|}{ Persentase Aktivitas Siswa } & \multirow{3}{*}{$\begin{array}{c}\text { Batas } \\
\text { waktu } \\
\text { toleran } \\
\text { si }(\%)\end{array}$} & \multirow{3}{*}{$\begin{array}{c}\text { Keefek } \\
\text { Tivan }\end{array}$} \\
\hline & \multicolumn{4}{|c|}{ Pertemuan Ke- } & \multirow[b]{2}{*}{$\begin{array}{c}\text { Rata- } \\
\text { Rata }\end{array}$} & & \\
\hline & 1 & 2 & 3 & 4 & & & \\
\hline $\begin{array}{l}\text { 1. Memperhatikan penjelasan guru dan } \\
\text { siswa }\end{array}$ & 31.86 & 17.57 & 15.93 & 14.6 & 19.4 & $15-25$ & Efektif \\
\hline 2. Membaca (Modul, Lembar Kerja) & 5.24 & 9.41 & 5.31 & 8.53 & 7.2 & $5-15$ & Efektif \\
\hline 3. Menulis (yang relevan dengan KBM) & 16.83 & 13.83 & 8.02 & 9.65 & 11.85 & $0-10$ & Efektif \\
\hline 4. Mengerjakan/menyelesaikan masalah & 19.86 & 28.12 & 32.66 & 32 & 28.6 & $28-38$ & Efektif \\
\hline $\begin{array}{l}\text { 5. Berdiskusi/bertanya antar siswa dan } \\
\text { antar siswa dan pengajar }\end{array}$ & 21.79 & 22.79 & 30,51 & 25.9 & 25.4 & $22-32$ & Efektif \\
\hline $\begin{array}{l}\text { 6. mengkomunikasikan hasil kerja } \\
\text { kelompok }\end{array}$ & 0 & 3.29 & 4.86 & 5.39 & 3.5 & $0-10$ & Efektif \\
\hline $\begin{array}{l}\text { 7. perilaku yang tidak relevan dengan } \\
\mathrm{KBM}\end{array}$ & 4.41 & 4.99 & 2.71 & 3.9 & 4 & $0-5$ & Efektif \\
\hline
\end{tabular}


menganalisa data aktivitas siswa selama kegiatan pembelajaran model dirrect instruction dengan strategi motivasi ARCS, respon siswa terhadap pembelajaran model dirrect instruction dengan strategi motivasi ARCS, dan hasil belajar siswa selama mengikuti kegiatan pembelajaran model dirrect instruction dengan strategi motivasi ARCS.

\section{Aktivitas Siswa}

Berdasarkan hasil pengamatan dari para pengamat mengenai aktivitas siswa selama pembelajaran dengan model dirrect instruction dengan strategi motivasi ARCS dapat dilihat pada Tabel 2.

Dari Tabel 2 tampak bahwa jika dilihat secara keseluruhan terdapat semua kategori pengamatan efektif karena rata-rata pada semua kategori pengamatan terletak pada batasan toleransi keefektifan. Karena semua kategori pengamatan efektif maka dapat disimpulkan bahwa aktivitas siswa selama kegiatan pembelajaran dengan menerapkan model pembelajaran dirrect instruction dengan strategi motivasi ARCS pada mata kuliah matematika diskrit materi graph tergolong efektif.

\section{Respon siswa}

Berdasarkan data hasil angket respon siswa yang terkumpul dari 27 orang siswa diperoleh rincian sebagai berikut

a) Pendapat siswa tentang komponen mengajar kategori senang/tidak senang

\begin{tabular}{|l|c|c|}
\hline $\begin{array}{c}\text { Komponen } \\
\text { Mengajar }\end{array}$ & $\begin{array}{c}\text { Senang } \\
(\boldsymbol{\%})\end{array}$ & $\begin{array}{c}\text { Tidak } \\
\text { Senang (\%) }\end{array}$ \\
\hline Materi Pelajaran & 100 & 0 \\
Lembar Kerja & 100 & 0 \\
Modul & 100 & 0 \\
Suasana kelas & 96 & 4 \\
\hline \multicolumn{1}{|c|}{ Rata-Rata } & 99 & 1 \\
\hline
\end{tabular}

b) Pendapat siswa tentang ada atau tidanya kesulitan dalam mempelajari materi pelajaran, mengerjakan lembar kegiatan, dan berdiskusi dalam kelompok.

\begin{tabular}{|c|c|c|c|}
\hline Keterangan & $\begin{array}{c}\text { Ya } \\
(\mathbf{\%})\end{array}$ & $\begin{array}{c}\text { Kadang- } \\
\text { Kadang } \\
(\mathbf{\%})\end{array}$ & $\begin{array}{c}\text { Tidak } \\
(\mathbf{\%})\end{array}$ \\
\hline $\begin{array}{l}\text { Apa Anda mengalami } \\
\text { kesulitan mempelajari materi } \\
\text { pelajaran, mengerjakan } \\
\text { lembar kerja, dan berdiskusi } \\
\text { dalam kelompok Anda? }\end{array}$ & 19.2 & 15.4 & 65.4 \\
\hline
\end{tabular}

c) Pendapat siswa tentang ada atau tidanya kesulitan pada kegiatan diskusi kelas

\begin{tabular}{|c|c|c|}
\hline Keterangan & Ya (\%) & $\begin{array}{c}\text { Tidak } \\
(\%)\end{array}$ \\
\hline $\begin{array}{lr}\text { Apakah Anda mengalami } \\
\text { kesulitan pada kegiatan diskusi } \\
\text { kelas, misalnya pada } & \text { saat } \\
\text { menyajikan hasil } & \text { kerja } \\
\text { kelompok, menanggapi hasil } \\
\text { kerja kelompok lain, dsb? }\end{array}$ & 8 & 92 \\
\hline
\end{tabular}

d) Pendapat siswa tentang lebih menarik dan bermanfaat mana antara KBM dengan model pembelajaran dirrect instruction dengan strategi motivasi ARCS atau KBM seperti yang dilakukan selama ini.

\begin{tabular}{|l|c|c|}
\hline Keterangan & $\begin{array}{c}\text { dirrect } \\
\text { instruction } \\
(\%)\end{array}$ & $\begin{array}{c}\text { konvensional } \\
(\%)\end{array}$ \\
\hline $\begin{array}{l}\text { Menurut Anda manakah yang } \\
\text { lebih menarik dan bermanfaat } \\
\text { bagi Anda, KBM dengan } \\
\text { menggunakan model } \\
\text { pembelajaran dirrect instruction } \\
\text { dengan strategi motivasi ARCS } \\
\text { ataukah KBM seperti yang } \\
\text { selama ini Anda ikuti }\end{array}$ & 92 & 8 \\
\hline
\end{tabular}

e) Pendapat siswa tentang setuju atau tidak jika dalam KBM selanjutnya digunakan model 
pembelajaran dirrect instruction dengan motivasi ARCS

\begin{tabular}{|c|c|c|}
\hline \multicolumn{1}{|c|}{ Keterangan } & $\begin{array}{c}\text { Ya } \\
(\mathbf{\%})\end{array}$ & $\begin{array}{c}\text { Tidak } \\
(\mathbf{\%})\end{array}$ \\
\hline $\begin{array}{l}\text { Apakah Anda setuju jika dalam } \\
\text { KBM selanjutnya digunakan model } \\
\text { pembelajaran dirrect instruction dengan } \\
\text { motivasi ARCS? }\end{array}$ & 96.2 & 3.8 \\
\hline
\end{tabular}

f) Pendapat siswa tentang keterbacaan modul (bahasanya)

\begin{tabular}{|c|c|c|}
\hline Keterangan & Ya (\%) & Tidak (\%) \\
\hline $\begin{array}{l}\text { Apakah komentar Anda } \\
\text { tentang modul yang Anda } \\
\text { gunakan. Apakah bahasanya } \\
\text { mudah dimengerti? }\end{array}$ & 92.3 & 7.7 \\
\hline
\end{tabular}

g) Pendapat siswa tentang keterbacaan lembar kegiatan (bahasanya), kejelasan urutan kerjanya, dan variasi soalnya

\begin{tabular}{|c|c|c|}
\hline Keterangan & $\begin{array}{c}\text { Ya } \\
(\%)\end{array}$ & $\begin{array}{l}\text { Tidak } \\
(\%)\end{array}$ \\
\hline \multicolumn{3}{|l|}{$\begin{array}{l}\text { Apa Komentar Anda terhadap lembar } \\
\text { kerja yang Anda gunakan }\end{array}$} \\
\hline $\begin{array}{l}\text { 1. Apakah bahasanya mudah } \\
\text { dimengerti? }\end{array}$ & 100 & 0 \\
\hline 2. Apakah Urutan Kerjanya jelas? & 100 & 0 \\
\hline \multirow{2}{*}{$\begin{array}{l}\text { 3. Bagaimana variasi dan tingkat } \\
\text { kesulitannya }\end{array}$} & $\begin{array}{l}\text { Baik } \\
(\%)\end{array}$ & $\begin{array}{c}\text { Kurang } \\
\text { Baik } \\
(\%) \\
\end{array}$ \\
\hline & 92.3 & 7.7 \\
\hline
\end{tabular}

Dari hasil angket respon siswa tersebut dapat dibuat rangkuman respon siswa terhadap pembelajaran dengan menggunakan model pembelajaran dirrect instruction dengan strategi motivasi ARCS seperti pada Tabel 3.

Dari data pada Tabel 3 menunjukkan bahwa persentase yang terbesar dari rata-rata persentase setiap indikator berada dalam kategori senang, tidak ada kesulitan, tertarik, berminat, paham, jelas, dan baik sehingga respon siswa terhadap komponen pembelajaran dirrect instruction dengan strategi motivasi ARCS adalah positif dan siswa berminat untuk mengikuti pembelajaran selanjutnya dengan menggunakan model pembelajaran tersebut.

\section{Hasil Belajar Siswa}

Pelaksanaan tes dilakukan pada subyek penelitian sebanyak 27 mahasiswa. Ringkasan hasil tes adalah sebagai berikut.

\begin{tabular}{|l|c|}
\hline \multicolumn{1}{|c|}{ Keterangan } & $\begin{array}{c}\text { Data } \\
\text { Hasil Tes }\end{array}$ \\
\hline Rata-Rata Nilai & 80.75 \\
Banyaknya siswa & 27 \\
Banyak siswa yang mencapai nilai $\geq 60$ & 25 \\
Banyak siswa yang mencapai nilai $\geq 60(\%)$ & 92.59 \\
\hline
\end{tabular}

Dari hasil tersebut tampak bahwa penerapan model pembelajaran dirrect instruction dengan strategi motivasi ARCS untuk mengajarkan materi graph pada mata kuliah Matematika Diskrit bisa dianggap efektif, karena banyaknya siswa yang mencapai nilai di atas 60 sebanyak 25 dari 27 anak atau $92,59 \%$.

Karena banyaknya siswa yang mencapai nilai kelulusan sebesar $92.59 \%$ atau diatas 70 \% maka berdasarkan Peraturan Rektor Universitas Sebelas Maret Nomor: 475/J27/PP/2005 Bab IX tentang Penilaian Hasil Belajar Mahasiswa pada pasal 14 (3) a, ketuntasan belajar tercapai.

Keefektifan Pembelajaran Dengan Model

Pembelajaran Dirrect Instruction Dengan Strategi Motivasi ARCS 
Tabel 3. Rangkuman Respon Siswa terhadap Pembelajaran dengan Menggunakan Model

Pembelajaran Dirrect Instruction dengan Strategi Motivasi ARCS

\begin{tabular}{|c|c|c|c|}
\hline No. & Keterangan & $\begin{array}{c}\text { Rata- } \\
\text { Rata }(\%)\end{array}$ & Respon \\
\hline 1 & Kegiatan mengajar & 99 & Senang \\
\hline 2 & Melakukan kegiatan & 65.4 & Tidak kesulitan \\
\hline 3 & Melakukan diskusi kelas & 92 & Tidak kesulitan \\
\hline 4 & Ketertarikan dan kemanfaatan model pembelajaran & 92 & Tertarik \& manfaat \\
\hline 5 & dirrect instruction dengan motivasi ARCS & & \\
\hline 6 & $\begin{array}{l}\text { Minat KBM berikutnya dengan model pembelajaran } \\
\text { dirrect instruction dengan motivasi ARCS }\end{array}$ & 92 & Berminat \\
\hline 7 & Bahasa yang digunakan pada modul & 92.3 & Paham \\
\hline 8 & Bahasa yang digunakan pada lembar kegiatan & 100 & Paham \\
\hline 9 & Kejelasan urutan kerja lembar kegiatan & 100 & Jelas \\
\hline 10 & Variasi dan tingkat kesulitan soal pada lembar kegiatan & 92.3 & Baik \\
\hline
\end{tabular}

Berdasarkan kriteria keefektifan yang telah ditetapkan maka pembelajaran dengan menerapkan model pembelajaran dirrect instruction dengan strategi motivasi ARCS efektif untuk mengajarkan materi graph pada mata kuliah Matematika Diskrit. Keefektifan ini tercapai karena (1) ketuntasan belajar tercapai karena banyaknya siswa yang memperoleh nilai di atas 60 sebanyak $92.59 \%$, (2) aktivitas siswa selama mengikuti pembelajaran tergolong efektif karena dari 7 kategori pengamatan, kategori pengamatan 4, 5, dan 6 tergolong efektif, dan (3) respon siswa terhadap pembelajaran tergolong positif karena persentase yang terbesar dari rata-rata persentase setiap indikator berada dalam kategori senang, tidak ada kesulitan, tertarik, berminat, paham, jelas, dan baik.

\section{PENUTUP}

Model pembelajaran dirrect instruction dengan strategi motivasi ARCS efektif diterapkan pada matakuliah matemátika diskrit materi graph pada mahasiswa program studi pendidikan matemátika Fakultas Keguruan dan ilmu Pendidikan Universitas Sebelas Maret. Hal ini disebabkan pada penerapan model pembelajaran tersebut:

1. Aktivitas siswa efektif selama kegiatan pembelajaran dengan Model pembelajaran dirrect instruction dengan strategi motivasi ARCS, karena rata-rata pada semua kategori pengamatan terletak pada batasan toleransi keefektifan.

2. Respon siswa terhadap komponen pembelajaran dirrect instruction dengan strategi motivasi ARCS adalah positif karena persentase yang terbesar dari ratarata persentase setiap indikator pada angket respon siswa berada dalam kategori senang, tidak ada kesulitan, tertarik, berminat , paham, jelas, dan baik.

3. Ketuntasan siswa tercapai karena banyaknya siswa yang tuntas belajar sebanyak 25 siswa dari 27 siswa atau sebesar $92.59 \%$ (lebih dari 70\%).

\section{DAFTAR PUSTAKA}

Arends, R. I. 1997. Classroom Instruction and Management. New York: Mcraw-Hill. 
2001. Learning to Teach. Fourth Edition. New York: Mcraw-Hill Higher Education.

Carrin, arthur. A. 1993. Teaching Modern Science. Sixth Edition. New York: Macmillan Publishing Company.

Hudojo, Herman. 1988. Mengajar Belajar Matematika. Jakarta : Dirjen Dikti P2LPTK.

Kardi, Soeparman. 1997. Direct Instruction, Penemuan Terbimbing dan Investigasi Kelompok. IKIP Surabaya.

Kardi, S dan Nur, M. 2000. Pengajaran Langsung. Surabaya: University Press Surabaya.

Keller, Jhon. ARCS Model, P.5, 2007 (http://www.arcsmodel.com/home.htm ).

Nur, Muhammad. 1998. Teori Pembelajaran Sosial. IKIP Surabaya.

Soedjadi, R. 1991. Belajar dan Faktor-Faktor yang Mempengaruhinya. Cetakan Kedua. Jakarta: Rineka Cipta. 1992. Pokok-Pokok Pikiran tentang Orientasi Masa Depan Matematika Sekolah di indonesia. Media Pendidikan Matematika Nasional No. 2 Th 1. 